DOI: $10.17516 / 1997-1370-0225$

УДК 340.11

\title{
H.L.A. Hart's Methodology of Defining Legal Concepts: Problems of Connection Between Semantics and Pragmatics in Legal Language
}

\author{
Sergei N. Kasatkin* \\ Samara State University of Economics \\ Samara, Russian Federation
}

Received 25.08.2017, received in revised form 09.01.2018, accepted 16.01.2018

\begin{abstract}
The subject of this article is a method of jurisprudential definition introduced by a British philosopher and jurist H.L.A. Hart. In particular it discusses: (1) the author's account of specificity of legal discourse (meaning and speech function of legal concepts) and discrepancy between that and a traditional method of definition per genus et differentiam; (2) Hart's alternative method of "philosophical definition" of legal concepts; (3) correlation of this method with other definitive / explanatory techniques used by the author in 1949-1961 papers and further; (4) complexities of jurisprudential and philosophical character related to Hart's method. Special attention is paid to Hart's position as to relationship between semantics and pragmatics in legal discourse (and so in "philosophical definition"). The conclusion is established claiming a change of the author's corresponding views: a transition to a looser type of connection between meaning and force of legal concepts in which these concepts (while maintaining its social, institutional character) can be used both in descriptive ("external") and "ascriptive" / normative ("internal") statements.
\end{abstract}

Keywords: H.L.A. Hart, legal language, legal concepts, jurisprudential definition, ascriptivity, legal semantics, legal pragmatics, analytical philosophy of law, jurisprudential methodology.

The publication is prepared under financial support of Russian Foundation for Fundamental Research, the project "Methodology of Analysis of Legal Language in Herbert Hart's Works: From The Doctrine of Ascriptivism and Defeasibility of Legal Concepts To The Project of Analytical Jurisprudence" No. 16-03-00804.

Research area: law.

Citation: Kasatkin S.N. (2022) H.L.A. Hart's methodology of defining legal concepts: problems of connection between semantics and pragmatics in legal language. J. Sib. Fed. Univ. Humanit. Soc. Sci., 15(3), 423-428. DOI: 10.17516/1997-1370-0225.

(C) Siberian Federal University. All rights reserved

* Corresponding author E-mail address: kasatka_s@bk.ru ORCID: 0000-0001-5541-9181 


\section{Introduction}

A classic method of conceptual definition per genus et differentiam (by specifying genus and species differences) is very common in modern social sciences and humanities, including jurisprudence. This method and a philosophical theory associated with it has become an object of discussion and criticism by Herbert L.A. Hart (1907-1992) - a representative of the Oxford school of philosophical analysis of ordinary language and a legal scholar, who offered a powerful alternative methodology of explaining legal concepts.

In this context the proposed article would focus on (1) a study of Hart's position as to an appropriate method for defining legal concepts, and on (2) stating some difficulties concerning this approach in light of traditional jurisprudence as well as of general philosophical-analytical doctrine, with a special emphasis on connection between semantics and pragmatics of legal usage.

\section{H.L.A. Hart: specificity of legal concepts and a method of their definition}

Hart starts from a philosophical-analytical doctrine of meaning as (language) use. However, he employs it not in a version of "language games" à la L. Wittgenstein (Wittgenstein, 1953), but in the context of performatives conception, advanced by J.L. Austin (Austin, 1961). Austin doesn't just reproduce Wittgenstein's thesis about social-practical, conventional-normative basis of linguistic meanings (suggesting to explain them through different examples of their use). He develops a doctrine about various forms of use (or speech functions) of linguistic expressions, formulating an idea of "performatives" as speech acts opposed to simple descriptions ("constatives") (Austin, 1961).

Hart applies ideas of diversity of speech functions to the so-called "social" concepts, primarily to concepts (terms) of legal language, such as "contract", "crime", "property", "action", "state", "corporation", "right", "duty", etc. (Hart, 1949; 1983a; 1955; 1957). According to the philosopher, in contrast to "natural" classes (terms like "chair" or "cat") social concepts have no direct empirical referents, their content is determined purely by a normative-institutional speech context, by an existing system of their use. In turn, as Hart argues, a typical form of their use - in expressions like "It's yours", "He did it", "Hereby I give you...", "He has a right / a duty...", etc. - is not a description, but something what Hart at different times calls an "ascription", an "operation with rules" (an operative or a performative), a "drawing [normative] conclusions" (qualification of a particular case) (Hart, 1949; 1983a, s. II-III; etc.). In other words in his initial (1953) explanation of legal concepts the author inextricably links their semantics and pragmatics, actually inferring the former from the latter (Kasatkin, 2014, ch. 2, §5).

As a result Hart rejects a classic method of definition per genus et differentiam (that supposes a universal rule of translation of a term in question into other (familiar) terms or suggests a formula of always necessary and sufficient conditions of a term's use). According to Hart, in relation to legal concepts such method is misleading, directing to description paradigms and to a search for empirical referents where they are absent (besides demanding certainty where it doesn't exist) (Hart, 1949; 1983a, s. II-III). In contrast to that in his 1950s works (starting from 1953 Definition and Theory in Jurisprudence) the author proposes a distinctive method of "philosophical definition", combining these concepts' semantic and pragmatic aspects. It involves: 1) an analysis of the concepts / terms in whole characteristic statements taken in typical socio-linguistic contexts of their use; 2) explication conditions of "truth-value" / appropriateness of their use as well as of their specific speech function (context and goal) (Hart, 1983a, s. II-III; 1955, s. II; 1957, s. II).

A famous example of application of Hart's method is his account of a concept (or an expression) "legal right":

1) A statement of the form " $X$ has a right..." is true (appropriate) if the following conditions are satisfied:

a) there is an existing legal system;

b) under rules of the system some other person $\mathrm{Y}$ in certain circumstances is obliged to do or refrain from some action; 
c) this obligation is made by the law dependent on a choice of $X$ (or a person authorized to act on his behalf), so that either $\mathrm{Y}$ is obliged to door refrain from some action only if this is a choice of X (or another person), or until $X$ (or another person) chooses otherwise.

2) A statement of the form " $X$ has a right" is used for drawing a legal conclusion in a particular case which falls under relevant rules (Hart, 1983a: 35).

Another typical instance is Hart's definition of a concept "legal person" ("corporation") with an example concerning the name of a fictional state "Nusquamia". According to the author, "to elucidate it we must... take the whole statement 'Nusquamia owes you £1000' and describe its use perhaps as follows:

1. Here in the territory of Nusquamia there is a legal system in force; under the laws of this system certain persons on complying with certain conditions are authorized for certain purposes to receive sums of money and to do other actions analogous to those required to make a contract of loan between private individuals.

2. When such persons do such acts certain consequences, analogous to those attached to the similar actions of private individuals, follow, including the liability of persons defined by law to repay the sums of money out of funds defined by law.

3. The expression 'Nusquamia owes you $£ 1000$ ' does not state the existence of these rules nor of these circumstances, but is true in a particular case when they exist, and is used in drawing a conclusion of law from these rules in a particular case" (Hart, 1983a: 38-39).

In regard to Hart's proclaimed method of definition it's necessary to pay attention to a number of points.

First, relatively brief "definitions" cited here are ones among few quite well-composed, compact and structured "philosophical definitions" presented in the author's texts. In Hart's other writings there are either much more lengthy explanations of legal concepts (e.g., a concept of legal obligation (Hart, 1957: 965-967) or even a concept of law (Hart, 1994)) or, on the contrary, only comments about the individual (obscured) features of explained concepts without explicating all elements valuable for its definition (along the 1953 method).

Second, in Hart's works one can find various types of explanatory / definitive techniques concerning legal and alike concepts, such as: (a) a technique of defining "open" and defeasible social concepts (Hart, 1949, s. I); (b) a technique of explaining concepts with a complex structure ("umbrella terms") (Hart, 1955, s. III); (c) techniques of explanation of ambiguity (diverse / logically non-unified use) and indeterminacy (vagueness) of legal concepts (Hart, 1957, s. IIIc); (d) techniques of explanation of legal "operatives" or performatives (Hart, 1949, s. II; 1955, s. II; 1957, s. II; etc.). Although Hart doesn't clarify their precise relationship with the 1953 method / approach the latter can be seen as a more general or framework method of definition, toward which the subsequent techniques act as particular, specifying elements (instantiations). These accent (and analytically isolate) either questions of semantics or questions of pragmatics of legal usage (Kasatkin, 2016).

Third, the 1953 method differs from the method / approach of "defining" a concept of law in the famous eponymous treatise of 1961. As before, the 1961 method is motivated by rejection of traditional concise definitions and "closed" logical formulas and is a technique of explanation of a complex concept and / or an ambiguous and vague ("open") concept. It involves composing a taxonomy of use of a concept, revealing its clear and borderline cases, analyzing their structure, relationships, principles of usage, etc. (Hart, 1994, ch. I). However, in contrast to the 1953 approach, the 1961 method rather starts from a subject-matter issues, its most acute problems ("persistent questions": relationship between law, coercion and morality, understanding of legal rule, etc. (Hart, 1994, ch. I) and also contains relevant important considerations and arguments of "non-linguistic" nature. Herewith, of course, key elements and analytic techniques of the 1950s are seen in the 1961 treatise in discussing the mentioned specific issues (relations between specific concepts), including the famous dis- 
tinction between "internal" and "external" statements based on earlier differentiation of ascriptive and descriptive speech functions (Hart, 1994, ch. IV-V, etc.).

\section{Jurisprudential \\ and philosophical complications \\ of H.L.A. Hart's methodology}

Hart's approach is of interest as a significant variant of justification of a general descriptive value-neutral theory and methodology of law concentrated on a study of "conceptual framework" of legal thought and contributing fruitful ideas of analytical-linguistic philosophy into jurisprudence. However, this approach poses several difficulties of both jurisprudential and philosophical character.

As for a jurisprudential aspect, Hart, first, focuses on "philosophical" rather than "technical" definitions, i.e. on explanation of specific nature of legal concepts, their meaning, relations to norms and facts, their speech functions, etc., and not on fixation of correct use of relevant terms within a legal system, their place in existing classifications (Hart, 1955, s. II; 1957, s. IIIa, IIId). Hence Hart's analytical jurisprudence converted along the model of philosophical-linguistic studies à la J.L. Austin and others, separates itself from discussing a number of traditional problems of (general and branch) legal dogma and practice (Bodenheimer, 1956).

Second, Hart's methodology provides an analytical and value-neutral description / explanation of basic legal concepts, centering its typical, "clear" cases of language usage (Hart, 1955, s. V; 1957, s. IIIa). As a consequence, this approach doesn't offer doctrinal justification of legal decisions, including one in situations of uncertainty (Dworkin, 1977); value assessment of normative systems and substantiation of an obligation to follow legal rules, especially in relation to vicious political regimes and immoral official regulations (Fuller, 1958); empirical formalization and verification of its theoretical claims (Leiter, 2003).

Nevertheless, it should be noted that similar difficulties (partly recognized by the British jurist), on one hand, is inherent in the tradition of analytical jurisprudence as a whole, on the other hand, it doesn't negate importance of Hart's project with its unique methodological tools, its relevance in modern legal theory.

Apart from jurisprudential issues the considered method of defining legal concepts gives rise to various questions of philosophical character, including those addressing connection between semantics and pragmatics of legal language.

Thus, first, in contrast to Hart's claims, a type of linking semantic and pragmatic aspects of discourse practiced by the author is not consistent in style with that of J.L. Austin (a fortiori with that of L. Wittgenstein). Austin rather explores these issues separately, in different kinds of research (Austin, 1961; 1962).

Second, and more important, claiming an "ascriptive" or non-constative character of legal concepts (causing inseparability of their semantics and pragmatics and a key role of the latter) Hart, despite Austin, confuses different aspects of a non-descriptivity: on one hand, an absence of exclusive empirical referents (material facts), on the other hand, a specific "force" or speech function (producing speech acts different from description). From the very author's examples already follows a possibility of descriptive use of such "ascriptive" terms (e.g., pronouncing "This is mine" for a statement of fact (Hart, 1949, s. II)), and vice versa (a directive in court judgments as to violation of rules concerning production of furniture or pets treatment). This in turn erodes peculiarities of legal concepts, pointing to more general patterns of language, and also impedes an explicit differentiation of legal discourse: it's unclear whether its specificity consists in its characteristic terminology or way of its use (Kasatkin, 2014, ch. 2, § 1).

As a result (in 1955 essay, in The Concept of Law, etc.), Hart retreats from such a rigid connection between semantics and pragmatics (Hart, 1955, s. III; 1994, s. IV-V, etc.), taking as an error his confusing a use as a meaning and as a "force" (speech function) (Hart, 1983b, s. I-II). In this view the same (social / legal) concept can be employed in different ways (speech acts), in "internal" and "external" statements, i.e. both from a "participant"'sperspective (a 
rules-basedoperation or qualification) and from a perspective of an "observer" (a description or a prediction of behavior in a normative system). Anyway, for Hart such a retreat doesn't mean a return to a traditional "closed" or ostensive definition, but rather a "broader" look at a link of semantic and pragmatic issues (allowing for different types of their relations in language practices) as well as adherence to other meth- ods of conceptual analysis grasping specificity of basic legal concepts.

In this form H.L.A. Hart's method of defining legal concepts proceeds in line with a philosophical-analytical methodology of his time, remaining open to reassessment through a light of subsequent theories about connection between semantics and pragmatics and corresponding jurisprudential doctrines.

\section{References}

Austin, J.L. (1961). Meaning of a Word. In Austin, J.L. Philosophical Papers. Oxford: Clarendon Press. $55-75$.

Austin, J.L. (1962). How to Do Things with Words. Oxford: Clarendon Press. 174 p.

Bodenheimer, E. (1956). Modern Analytical Jurisprudence and the Limits of Its Usefulness. In University of Pennsylvania Law Review. (104), 1080-1086.

Dworkin, R. (1977). Taking Rights Seriously. Cambridge, Ma.: Harvard University Press. XV, 293 p.

Fuller, L. (1958). Positivism and Fidelity to Law: A Reply to Professor Hart. In Harvard Law Review. (71), 630-672.

Hart, H.L.A. (1949). The Ascription of Responsibility and Rights. In Proceedings of the Aristotelian Society. (49), 171-194.

Hart, H.L.A. (1955). Theory and Definition in Jurisprudence. In Proceedings of the Aristotelian Society. (29), 239-264.

Hart, H.L.A. (1957). Analytical Jurisprudence in Mid-Twentieth Century: A Reply to Professor Bodenheimer. In University of Pennsylvania Law Review.(105), 953-975.

Hart, H.L.A. (1983a [1953]). Definition and Theory in Jurisprudence. In Hart, H.L.A. Essays on Jurisprudence and Philosophy. Oxford: Clarendon Press. 21-48.

Hart, H.L.A. (1983b). Introduction. In Hart, H.L.A. Essays in Jurisprudence and Philosophy. Oxford: Clarendon Press. 1-18.

Hart, H.L.A. (1994 [1961]). The Concept of Law. $2^{\text {nd }}$ ed. with Hart's Postscript. Oxford: Clarendon Press. XII, 315 p.

Kasatkin, S.N. (2014). Kak opredeliat' sotsial'nyie poniatiya? Konseptsiya ascriptivizma i otmeniayemosti iuridicheskogo iazyka Gerberta Kharta: monografiya [How to define social concepts? Herbert Hart's Conception of ascriptivism and defeasibility of legal language: a monography]. Samara: Samara Academy of Humanities. $472 \mathrm{p}$.

Kasatkin, S.N. (2016). Opredeleniye v analiticheskoiy urisprudentsii G. Kharta 1950-kh gg.: filosofskiye i pravovedcheskiye aspecty [Definition in H. Hart's 1950s analytical jurisprudence: philosophical and jurisprudential aspects]. In Problemy metodologii i filosofii prava: statyi uchastnikov III mezhdunarodnogo kruglogo stola [Problems of methodology and philosophy of law: articles of participants of the III international round table]. Samara: Samara Academy of Humanities Press. 99-112.

Leiter, B. (2003). Beyond the Hart/Dworkin Debate: The Methodology Problem in Jurisprudence. In American Journal of Jurisprudence. (48), 17-51.

Wittgenstein, L. (1953). Philosophical Investigations. Oxford: Blackwell. 


\title{
Методология определения правовых \\ понятий Г.Л.А. Харта: проблемы связи семантики \\ и прагматики в юридическом языке
}

\section{С.Н. Касаткин}

Самарский государственный экономический университет

Российская Федерачия, Самара

\begin{abstract}
Аннотация. Предмет настоящей статьи - метод правоведческого определения, вводимый британским философом и правоведом Г.Л.А. Хартом. Здесь, в частности, разбираются: 1) авторская трактовка специфики юридического дискурса (значения и речевой функции правовых понятий) и несоответствие ей традиционного метода определения per genus et differentiam; 2) предлагаемый Хартом альтернативный метод «философского определения» правовых понятий; 3) соотношение данного метода с иными дефинитивными / объяснительными техниками, используемыми автором в работах 1949-1961 гг. и далее; 4) сложности правоведческого и философского характера, связанные с методом Харта. Особое внимание уделяется позиции Харта относительно связи семантики и прагматики в юридическом дискурсе (и «философском определении»). Обосновывается вывод об изменении соответствующих взглядов автора: о переходе к более свободному типу связи значения и силы правовых понятий, при котором последние (сохраняя свой «социальный», институциональный характер) могут употребляться как в описательных («внешних»), так и в «аскриптивных» / нормативных («внутренних») утверждениях.
\end{abstract}

Ключевые слова: Г.Л.А. Харт, юридический язык, правовые понятия, правоведческое определение, аскриптивность, правовая семантика, правовая прагматика, аналитическая философия права, методология юриспруденции.

Публикация подготовлена при финансовой поддержке РФФИ, проект «Методология анализа юридического языка в работах Герберта Харта: от доктрины аскриптивизма и отменяемости правовых понятий к проекту аналитической юриспруденции», № 16-03-00804.

Научная специальность: 12.00 .00 - юридические науки. 